\title{
PROBLEM PRAKTIK KHURÛJ BAGI ANGGOTA JAMA`AH TABLIGH DI MADURA*
}

\author{
Faiqoh Bahjah Lailatus Siyami \\ (Jurusan Syariah STAIN Pamekasan, Jl Raya Panglegur km 04, \\ email:faexzzzz_me@yahoo.com) \\ Siti Musawwamah \\ (Jurusan Syariah STAIN Pamekasan, Jl. Raya Panglegur km. 04, \\ email:mamahtaufiq@yahoo.com)
}

\begin{abstract}
Abstrak:
Khurûj adalah salah satu ajaran yang sangat melekat erat dengan Jama ah Tabligh yang mewajibkan setiap anggotanya untuk pergi ke luar daerah untuk menyiarkan amr al-ma 'rûf nahy al-munkar dalam waktu tertentu. Masalah utama adalah saat kewajiban khurûj dihadapkan dengan kewajiban dalam keluarga. Kewajiban tersebut dapat menimbulkan masalah saat anggota Jama`ah Tabligh tidak dapat menyeimbangkan kewajiban untuk keluarga dan kewajiban khurûj. Seperti perceraian pada salah satu keluarga anggota Jama`ah Tabligh. Penyebab perceraian adalah karena kurangnya nafkah saat suami khurûj, untuk menutupi kekurangan, isteri memilih menumpuk hutang sampai tidak mampu melunasi. Melakukan khurûj adalah kegiatan dalam Jama`ah Tabligh, dimana seorang anggota akan diakui sebagai anggota resmi saat sudah turut serta dalam melakukan khurûj. Konsep khurûj dalam aplikasinya terbagi menjadi tiga tahap. Pertama, 3 hari dalam sebulan; kedua, 40 hari dalam setahun dan ketiga, 4 bulan sekali seumur hidup. Namun, hitungan dakwah ini ditetapkan tanpa diketahui menggunakan dasar Al-Qur'an dan al-Sunnah yang jelas, ataupun manhaj dakwah yang dicontohkan oleh Rasulullah. Sedangkan Jama'ah Tabligh dalam konsep khurûj-nya menggunakan ayat Al-Qur'an sebagai landasan teoritis. Yaitu kalimat 'ukhrijat' yang terkandung dalam QS. Ali Imran [3]:110.
\end{abstract}

\footnotetext{
* Tulisan ini artikel ringkasan penelitian individual tugas akhir prodi AHS Jurusan Syariah STAIN Pamekasan
} 
Faiqoh Bahjah Lailatus Siyami

\begin{abstract}
:
Khurûj is one of the teachings which is tightly attached to Jama ah Tabligh that ordered all its followers to go out of the district/area to spread amr al-ma rûf nahy al-munkar in a certain time. The main problem is when the khurûj obligation is faced to Family obligation. Those obligations can create problems when the member of the Jama ah Tabligh cannot make the obligation to the family and the khuruij obligation balance. One of the examples is the divorce of the member of the Jama 'ah Tabligh. The reason of the divorce is because the lack of living cost when the husband did the khurûj. To fulfill it, the wife gets debt from other people and she cannot pay it off. Doing the khurûj is an activity of Jama 'ah Tabligh, where a member will be stated as a legal member when he has joined the khurûj. Khurûj concept in its application is devided into 3 phases. The First is 3 days in a month; the second is 40 days in a year, and the last is 4 months in a lifetime. But the theory of the counting is using unknown and unclear base either from Al-Qur'an and al-Sunnah or any other methods of dakwah that applied by Rasulullah. While Jama'ah Tabligh uses Saying from Al-Qur'an as theoretical foundation about khurûj, that is the word "ukhrijat" containing in QS. Ali Imran (3): 110.
\end{abstract}

Kata Kunci:

Khurûj, Nafkah, Hak dan Kewajiban Suami-istri, amr al-ma` rûf nahy al-munkar

\title{
Pendahuluan
}

Para ulama sepakat bahwa menyerukan amr al-ma 'rûf nahy almunkar merupakan sebuah kewajiban atau disebut dengan fardhu. Berdakwah merupakan bagian dari amr al-ma`rûf nahy al-munkar. Berkaitan dengan kedudukan kewajiban tersebut terjadi perbedaan pendapat. Sebagian ulama seperti Ibnu Katsir mengatakan bahwa menyerukan amr al-ma 'rûf nahy al-munkar merupakan sebuah fardhu 'ain. Pendapat tersebut berlandaskan kepada QS. Ali Imran [3]: 104.

Ibnu Katsir menambahkan bahwa fardlu 'ayn yang dimak sudkan Allah dalam ayat tersebut adalah kepada sebagian golongan. Sedangkan kelompok kedua mengatakan bahwa amr al-ma`rûf nahy al-munkar merupakan fardhu kifâyah. Pendapat tersebut salah satunya disampaikan oleh Ibnu Taymiyah dan al-Nawawî. 
Dasar dari pendapat tersebut juga merujuk pada ayat yang sama, namun Ibnu Taymiyah berpendapat dalam kitabnya Majmû'at al-Fatawâ bahwa dalam ayat tersebut merupakan ketentuan terhadap sebagian kelompok saja. Jika sebagian kelompok sudah memenuhi kewajiban tersebut maka kewajiban atas kelompok lain dalam wila yah tersebut telah gugur. ${ }^{1}$

Berdakwah merupakan kegiatan keagamaan yang membutuh kan daya juang dan stamina. Tidak heran jika pendakwah rata-rata adalah kaum laki-laki. Laki-laki memiliki banyak sekali beban kewajiban yang harus dipikulnya kepada Tuhan, masyarakat, dan keluarga. Laki-laki adalah tulang-punggung lingkup terkecil sosial, yaitu keluarga.

Karena itu seorang suami harus mampu mensejahterakan keluarganya baik dari nafkah kiswah (pakaian), nafkah maskanah (tempat tinggal), dan nafkah belanja kebutuhan pokok sehari-hari. ${ }^{2}$ Nafkah kiswah merupakan kewajiban suami untuk memenuhi kebu tuhan keluarga dari segi sandang yang merupakan kebutuhan untuk menutupi aurat demi menjaga kehormatan diri dan suami.

Nafkah maskanah merupakan tempat yang layak dihuni oleh keluarga agar bisa memberikan rasa aman, nyaman, dan tentram sebagaimana firman Allah dalam QS. Al-Thalaq [65]: $6^{3}$

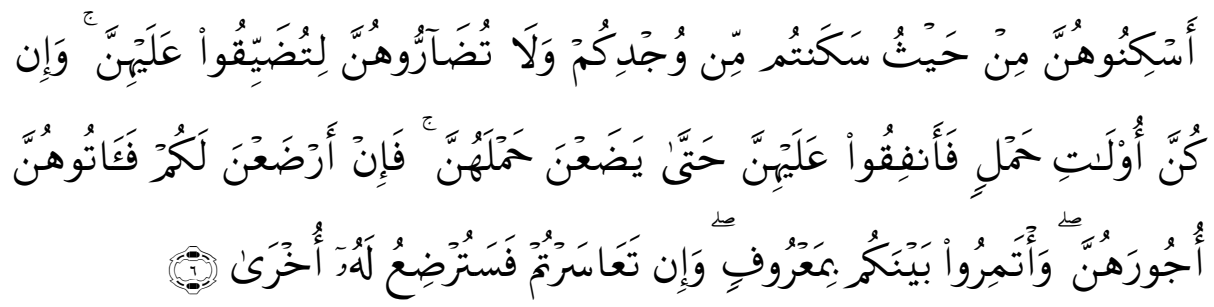

tempatkanlah mereka (para isteri) di mana kamu bertempat tinggal menurut kemampuanmu dan janganlah kamu menyusahkan mereka untuk menyempitkan (hati) mereka. dan jika mereka (isteri-isteri yang sudah ditalaq) itu sedang hamil, Maka berikanlah kepada mereka nafkahnya hingga mereka bersalin, kemudian jika mereka menyusukan (anak-anak)mu untukmu, Maka berikanlah kepada mereka upahnya, dan musyawarahkanlah di antara kamu (segala sesuatu) dengan baik, dan

1 Muhammad As-Sayyid Yusuf et.al, Ensiklopedi Metodologi Al-Quran 1 Terjemah, (Mesir: Dar As-Salam Maktabah Al-Usrah), hlm. 92

2 Beni Ahmad Saebani, Fiqih Munakahat 2 (Bandung: CV. Pustaka Setia, 2010), hlm. 32

${ }^{3}$ Departemen Agama RI, Mushaf Aisyah, hlm. 559 
jika kamu menemui kesulitan, Maka perempuan lain boleh menyusukan (anak itu) untuknya.

Menurut Hamka ayat di atas merupakan kewajiban mutlak yang harus dipenuhi seorang laki-laki yang telah menikahi seorang perempuan. Sejak sebelum terjadi pernikahan laki-laki harus telah mempersiapkannya. Tapi kewajiban yang harus dipenuhi oleh suami tidak diukur dari keinginan isteri melainkan menurut kelaziman tempat tinggal di mana suami berada. Sampai ketika terjadi perce raian pun Al-Quran mengatur pemberian nafkah dengan keten tuan hanya untuk perempuan yang bisa dirujuk lagi. ${ }^{4}$

Tanggung jawab tersebut berlaku kepada setiap laki-laki kepala keluarga tidak terkecuali anggota Jama`ah Tabligh yang mewa jibkan kepada setiap anggotanya untuk melakukan khurûj sehingga menyebabkan waktu bersama keluarga berkurang. Khurûj merupakan karakter yang membedakan organisasi ini dengan organisasi lainnya, yakni berdakwah keluar dari tempat ia tinggal melakukan perjalanan dakwah dari satu tempat ke tempat lainnya. ${ }^{5}$

Seorang kader Jama 'ah Tabligh akan diakui sebagai anggota resmi bila sudah turut serta dalam melakukan khurûj. Dengan khurûj, anggota Jama`ah Tabligh dinilai dapat meneguhkan diri untuk dapat bergabung dengan perjuangan Jama`ah Tabligh. Konsep aplikasi khurûj terbagi menjadi tiga tahap: ${ }^{6}$ pertama, 3 (tiga) hari dalam sebulan. Kedua, 40 (empat puluh) hari dalam setahun. Ketiga,4 (empat) bulan sekali seumur hidup.

Namun hitungan tersebut ditetapkan tanpa diketahui dasar nya dari Al-Qur'an ataupun manhaj dakwah yang dicontohkan oleh Rasulullah. Namun Jama`ah Tabligh berdalih bahwa dalam konsep khurûj-nya menggunakan ayat Al-Qur'an sebagai landasan teoritis. Yaitu kalimat 'ukhrijat' sebagaimana yang termaktub dalam QS. Ali Imran [3]: 110.7

\footnotetext{
${ }^{4}$ Hamka, Tafsir Al-Azhar juz XXVIII, (Jakarta : PT Pustaka Panjimas, 2005), hlm. 276

5 Asep Muhyiddin, Kajian Dakwah Multiperspektif, (Bandung : Rosda, 2014), hlm. 136 6http:/ / m.nu.or.id/a,public-m,dinamic-s,detail-ids,4-id,32537-lang,idc,kolomt,Jamaah+Tabligh-.phpx (diakses pada hari Jum'at tanggal 21 Maret 2014. 20.52 WIB)

7 Departemen Agama RI, Mushaf Aisyah, hlm. 64
} 


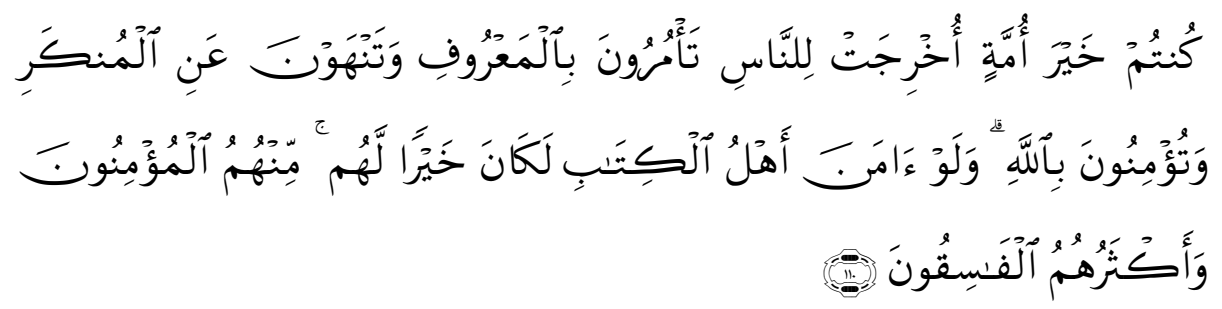

kamu adalah umat yang terbaik yang dilahirkan untuk manusia, menyuruh kepada yang ma' rûf, dan mencegah dari yang munkar, dan beriman kepada Allah. Sekiranya ahli kitab beriman, tentulah itu lebih baik bagi mereka, di antara mereka ada yang beriman, dan kebanyakan mereka adalah orang-orang yang fasik.

Kata 'ukhrijat' diartikan oleh Jama'ah Tabligh sebagai keluar dari rumah melakukan perjalanan untuk berdakwah. Surah ini menjadi landasan dakwah Jama`ah Tabligh karena mimpi yang datang pada pendiri pertama gerakan ini, yaitu Muhammad Ilyas Zakariya alKandahlawi, ${ }^{8}$ mengatakan bahwa tafsir dari ayat tersebut adalah "Keluar dari rumah dan melakukan perjalanan". 9

Sedangkan pendapat Quraish Shihab mengenai kata 'ukhrijat' yang secara lafal mengandung makna keluar ditafsirkan menjadi 'diwujudkan' dan 'ditampakkan'. Kalimat tersebut jika disambung de ngan kata sebelumnya, yakni kata 'ummat', maka mengandung tafsir ummat yang diwujudkan atau ditampakkan di dunia ini sebagai umat terbaik. 10

Jama 'ah Tabligh mempunyai kepercayaan bahwa melakukan khurûj mempunyai nilai pahala yang lebih besar daripada melakukan

8 Nama lengkap Muhammad Ilyas bin Syeikh Muhammad Ismail Dyupandi Al-Jisty Al-Kandahlawi. Jamaah tabligh pertama kali didirikan di kota selatan Delhi yang disebut dengan wilayah Mawat, India tepatnya pada tahun 1926 M gerakan dakwah tersebut berdiri. Masyarakat di sana telah lama menganut ajaran Islam sejak sekitar abad XII Masehi. Namun terjadi penurunan kualitas keislaman, ritual ibadah yang dilakukan oleh masyarakat Delhi tersebut sangat berbau takhayul dan mistik. Sehingga seperti ada percampuran dari ajaran Islam yang memang telah lama dikenal dengan ajaran agama Hindu.Lihat http://m.nu.or.id/a,public-m,dinamics,detail-ids,4-id,32537-lang,id-c,kolom-t,Jamaah+Tabligh-.phpx diakses pada tanggal 06 Sepetember 2014. 11.07 wib.

${ }^{9}$ http:/ / m.nu.or.id/a,public-m,dinamic-s,detail-ids,4-id,32537-lang,id-

c,kolomt,Jamaah+Tabligh-.phpx (diakses pada hari Jum'at tanggal 21 Maret 2014. 20.52 WIB)

${ }^{10}$ M. Quraish Shihab, Tafsir Al-Mishbah, Vol. 2, (Jakarta: Lentera Hati, 2005), hlm.173. 
rukun Islam yang kelima, yakni menunaikan ibadah haji ke Baitullah. Menurut mereka ibadah haji hanya akan mempunyai dampak baik terhadap diri sendiri, sedangkan berdakwah dengan metode khurûj akan memberikan manfaat terhadap diri sendiri dan masyarakat luas. ${ }^{11}$

Kitab yang menjadi pedoman dari setiap dakwah yang disampaikan oleh Jama ah Tabligh adalah kitab Fadhîlah amal yaitu kitab yang disusun oleh pendiri organisasi ini, Muhammad Ilyas Zakariya al-Kandahlawi (1885 M/1303 H). Sebagaimana diketahui dalam kitab tersebut terdapat banyak Hadits yang kualitasnya lemah bahkan palsu. Dalam kitab tersebut sebenarnya telah dijelaskan kedudukan dari setiap Hadits yang disusun oleh pengarangnya, namun keterangan kitab tersebut ditulis dalam bahasa Arab yang dalam kitab terjemahannya, deskripsi status Hadits tidak dituturkan secara jelas.

Dapat dinilai bahwa sebenarnya konsep khurûj yang dilakukan oleh Jama 'ah Tabligh tidak mempunyai landasan kuat dari Al-Qur'an dan Hadits, selain hanya berpegang terhadap mimpi yang datang kepada pendirinya, al-Kandahlawi. Namun demikian, khurûj sudah menjadi dogma di kalangan Jama`ah Tabligh termasuk anggota Jama ‘ah Tabligh yang berdomisili di kampung Paddhek desa Tlontoh Rajeh kecamatan Pasean kabupaten Pamekasan Madura. Para suami anggota organisasi keagamaan ini sering meninggalkan keluarganya pergi ke luar daerah bahkan ke luar negeri seperti India dan Pakistan untuk melakukan khurûj dalam waktu yang sudah ditentukan.

Khurûj yang dilakukan ke luar daerah dilakukan secara berka la dan rutin. Seperti namanya yang berarti "keluar", khurûj dilakukan dengan mengesampingkan kondisi keagamaan masyarakat sekitar yang masih membutuhkan pengayoman bahkan bantuan sarana prasarana untuk meningkatkan ibadah dan pengetahuan agama. Bahkan keluarga anggota Jama`ah Tabligh yang ditinggalkan dalam waktu yang tidak sebentar harus kehilangan sosok pelindung yang bisa memenuhi kebutuhan hidup baik lahir maupun bathin.

Secara ideal konsep khurûj, mensyaratkan pemberian nafkah haruslah dipersiapkan sebelum melakukan perjalanan khurîj dan

\footnotetext{
11http:/ /abusalma.wordpress.com/2007/01/03/studi-kritis-pemahaman-
} jamaahtabligh/(diakses pada hari Kamis tanggal 27 Maret 2014. 17.47 WIB) 
harus sepadan dengan kebutuhan dan lamanya khurûj. Hal tersebut sudah tentu dengan mendapatkan dukungan dari keluarga dan sau dara karena kegiatan tersebut adalah perjalanan dakwah untuk menegakkan ajaran agama Islam yang dibawa oleh Rasulullah.

\section{Metode Penelitian}

Penelitian ini merupakan penelitian kualitatif,12 penelitian ini berupaya untuk mendeskripsikan tentang bagaimana cara pemenu han hak dan kewajiban suami-isteri dalam Jama`ah Tabligh, apa saja kendala yang ditemui saat pemenuhan hak dan kewajiban tersebut, dan bagaimana perspektif hukum Islam dalam mengatur hal tersebut. Penelitian ini dibatasi oleh beberapa hal:

1. Khuruj adalah keluar dari daerah asal ke tempat yang lain yang jauh untuk berdakwah atau menyampaikan ajaran Islam dan menjadi kan masjid sebagai markas atau pusat kegiatan dakwah.

2. Jama'ah Tabligh adalah sebuah organisasi dakwah yang mempunyai ciri khas khuruj sebagai cara berdakwah.

3. Hukum Islam yang dimaksud adalah yang diatur dalam AlQuran, Hadits, dan ijma' ulama (4 Imam Madzhab), serta Ulama Indo nesia yang terangkum dalam Kompilasi Hukum Islam (KHI).

4. Pemenuhan hak dan kewajiban adalah melaksanakan kewajiban dan menerima hak suami-Isteri sesuai dengan hukum Islam dalam penelitian ini fokus kepada pemenuhan kewajiban materi yaitu uang belanja untuk keperluan sehari-hari keluarga dan kewajiban non materi yaitu perhatian untuk keluarga baik isteri ataupun anak.

Penelitian ini membutuhkan waktu selama tiga bulan di kampung Paddhek desa Tlontoh Rajeh kecamatan Pasean kabupaten Pamekasan. Peneliti terlibat dalam pengamatan langsung (non partisi

\footnotetext{
${ }^{12}$ Sugiono menyebutkan bahwa pendekatan kualitatif merupakan metode penelitian naturalistik karena penelitiannya dilakukan pada obyek dalam kondisi alamiah. Dalam istilah lain dapat dinyatakan bahwa penelitian kualitatif adalah penelitian yang bermaksud untuk memahami fenomena yang terjadi di masyarakat, seperti perilaku, persepsi, motivasi, dan tindakan. Penelitian kualitatif memiliki ciri yang sangat menonjol yaitu mendeskripsikan atau menggambarkan data secara mendalam dalam bentuk narasi. Sugiono, Metode Penelitian Kuantitatif Kualitatif dan RED, (Bandung: Alfabeta, 2011), hlm. 8.
} 
pan), baik dalam kegiatan rutin semisal pengajian, dakwah, dan kegia tan di masjid pusat kegiatan Jama'ah Tabligh ataupun dalam kehidu pan sehari-hari sebagian anggota Jama`ah Tabligh.

Metode pengumpulan data yang digunakan adalah wawanca ra, yang didukung dengan penggunaan metode observasi dan doku mentasi. Teknik wawancara yang digunakan adalah teknik wawan cara tidak terstruktur, yaitu wawancara bebas mengajukan perta nyaan tanpa mengacu pada pedoman wawancara yang telah disusun secara sistematis. ${ }^{13}$ Observasi ataupun pengamatan, tidak hanya terfokus pada orang, melainkan juga berhubungan dengan obyekobyek alam lain seperti perilaku manusia, proses kerja, gejala-gejala alam.

Dokumentasi merupakan data pendukung yang akan memban tu menguatkan penelitian dan pembuktian. Ada tiga macam sumber dokumentasi, yaitu tulisan, tempat, dan kertas atau orang. ${ }^{14}$ Doku mentasi yang digunakan dalam penelitian ini adalah, surat-surat, gam bar, rekaman, dan transkip wawancara.

Analisis data dilakukan dengan langkah-langkah sebagai beri kut: mencatat data dari lapangan, mengklarifikasi, mencari makna dari data yang diperoleh. ${ }^{15}$ Untuk pengecekan keabsahan data agar bisa dipertanggung, maka digunakan beberapa langkah: 1) perpanja ngan waktu observasi. ${ }^{16}$ 2) Triangulasi. ${ }^{17}$ 3) Ketekunan pengamatan. ${ }^{18}$ 4) Pengecekan sejawat. ${ }^{19}$ 5) Pengecekan anggota. ${ }^{20}$

\footnotetext{
${ }^{13}$ Sugiono, Metode, hlm. 140-145.

${ }^{14}$ Suharsimi Arikunto, Prosedur Penelitian (Jakarta: PT Rineka Cipta, 2010), hlm. 201.

${ }^{15}$ Lexy J. Moleong, Metodologi Penelitian Kualitatif, (Bandung: PT Remaja Rosdakarya, 2005), hlm. 248.

${ }^{16}$ Perpanjangan waktu observasi dilakukan jika dalam waktu yang telah ditentukan data masih belum lengkap maka harus dilakukan perpanjangan waktu observasi untuk melengkapi data-data tersebut. Untuk itu, peneliti melakukan perpanjangan waktu observasi karena terdapat data yang masih kurang. Penelitian yang awalnya direncanakan berakhir pada akhir januari dilanjutkan sampai bulan februari untuk lebih memvalidkan data yang telah diperoleh. Lexy J. Moleong, Metodologi Penelitian Kualitatif, hlm. 328.

17 Triangulasi adalah teknik konfirmatorik keabsahan data yang memanfaatkan sesuatu di luar dari data tersebut. Hal tersebut dilakukan untuk keperluan pengecekan untuk membandingkan terhadap data tersebut. Sebagai teknik ada 4 macam triangulasi yaitu dengan menggunakan sumber, metode, peneliti, dan teori. Lexy J. Moleong, Metodologi Penelitian Kualitatif, hlm. 330. Penelitian ini triangulasi yang digunakan adalah sumber, yakni peneliti membandingkan keseuaian hasil
} 


\section{Fenomena Khurûj Komunitas Jama`ah Tabligh di Kecamatan Pasean Pamekasan}

Khurûj adalah keluar dari daerah asal ke tempat yang lain untuk berdakwah dan menyampaikan ajaran Islam dengan menja dikan masjid sebagai markas atau pusat kegiatan dakwah. Berdasar pengamatan langsung terhadap komunitas Jama'ah Tabligh di kam pung Paddhek desa Tlontoh Rajeh kecamatan Pasean Kabupaten Pameksan, didapatkan temuan-temuan faktual penga malan konsep khurûj pengikut Jama'ah Tabligh di daerah tersebut. Walaupun tam pak tidak mudah, namun komunitas Jama`ah Tabligh memiliki cara mengatasi persoalan-persoalan yang muncul sebagai konse kuensi pengamalan konsep khurûj.

\section{Pemenuhan Hak dan Kewajiban Keluarga}

Adapun cara pemenuhan hak dan kewajiban yang di tempuh oleh suami-isteri anggota Jama`ah Tabligh di kampung Paddhek desa Tlontoh Rajeh kecamatan Pasean kabupaten Pamekasan adalah de ngan membuat aturan yang membahas tentang tahap-tahap yang harus dilakukan oleh para anggota sebelum melakukan khurûj.

wawancara dari semua informan. Teknik triangulasi lebih mengutamakan efektivitas proses dan hasil yang diinginkan. Oleh karena itu, triangulasi dapat dilakukan dengan menguji apakah proses dan hasil metode yang digunakan sudah berjalan dengan benar. Yaitu seperti mengadakan uji silang terhadap catatan hasil wawancara yang ada apakah terdapat pertentangan dari setiap hasil wawancara yang telah didapatkan. Dan jika ternyata ada informasi yang bertentangan dengan hasil lainnya maka penelitian harus mengkonfirmasi lagi tentang data tersebut. Burhan Bungin, Analisis Data Penelitian Kualitatif, Rajawali Press : Jakarta, 2010, hlm. 203.

${ }^{18}$ Ketekunan pengamatan sangat diperlukan untuk data yang sedang dikumpulkan. Ketekunan pengamatan bukan hanya tentang bagaimana peneliti dapat memperoleh data tapi juga tekun dalam menganalisis data sehingga analisis data tersebut tidak terpengaruhi oleh asumsi pribadi dari peneliti. Lexy J. Moleong, Metodologi Penelitian Kualitatif, hlm, 329.

${ }^{19}$ Pengecekan sejawat dilakukan ketika data yang telah diperoleh dan ditulis harus di check kembali kepada sesama peneliti dengan cara diskusi apakah data yang telah ditulis tersebut sudah akurat.. Lexy J. Moleong, Metodologi Penelitian Kualitatif, hlm, 332.

${ }^{20}$ Pengecekan anggota adalah pengecekan kembali data yang masih belum lengkap. Pengecekan anggota dilakukan dengan anggota yang terlibat dalam proses pengumpulan data sangat penting untuk mengetahui derajat validitas data. Lexy J. Moleong, Metodologi Penelitian Kualitatif, hlm, 335. 
Achmad Syarqawi menyatakan bahwa pemenuhan nafkah keluarga yang ditinggalkan dilakukan dengan model nafkah silang. Para istri yang ditinggalkan suaminya untuk berdakwah dan seluruh anggota Jama`ah, saling membantu. ${ }^{21}$

Haji Muhammad Saleh juga menuturkan bahwa para anggota mengadakan rapat sebelum pergi berdakwah untuk mengatur kebutu han nafkah keluarga yang akan ditinggalkan. Petikan wawancaranya sebagai berikut:

"Untuk masalah nafkah itu sudah diatur terlebih dahulu sebelum berangkat untuk Khurûj. Ada semacam rapat tentang pemenuhan nafkah ini. Jadi dalam rapat tersebut ditanyakan pada masingmasing anggota siapa yang siap untuk khurûj. Setelah mendapatkan nama-nama siapa yang siap untuk khurûj maka didiskusikan bagaimana nafkah untuk keluarga dari setiap anggota yang akan berangkat. Ditanyakan apa anggota yang siap berangkat itu sudah punya cukup nafkah untuk keluarga kalau nanti khurûj. Kalau tidak cukup dimusyawarahkan lagi siapa yang sanggup menanggung"22

Menurut penjelasan Haji Muhammad Saleh bahwa nafkah silang tersebut bukannya hanya dengan saling memberi melainkan juga dengan membantu pekerjaan ibu-ibu yang suaminya khurûj. Seperti membantu menggarapkan ladang pertanian ataupun dengan ikut membantu mengurus hewan peliharaan yang harus dicarikan rumput agar tidak mati. ${ }^{23}$

Secara spesifik kegiatan persiapan nafkah sebelum pergi untuk khurûj di daerah kampung Paddhek ini disampaikan oleh beberapa anggota perkumpulan wanita Jama ah Tabligh yang diberi nama per kumpulan Masturah. Istilah Masturah adalah istilah yang digunakan bagi kegiatan khusus anggota Jama`ah Tabligh wanita. Nyai Nikmah, sebagai pemberi materi pengajian menuturkan sebagaimana petikan wawancara berikut ini:

"Di daerah Paddhek ini setiap malam Rabu, di markas (masjid) ada

21 Wawancara dengan Achmad Syarqawi anggota Jamaah Tabligh, pada hari Kamis 08 Januari 2015

22 Wawancara dengan H. Muhammad Saleh anggota Jamaah Tabligh, pada hari Sabtu 17 Januari 2015

${ }^{23}$ Wawancara dengan H. Muhammad Saleh anggota Jamaah Tabligh, pada hari Sabtu 17 Januari 2015 
perkumpulan untuk musyawarah bagi para rijâl (anggota lakilaki). Tujuannya untuk mendengarkan keluh kesah dari para anggota, semisal sebelum pergi khurûj, ditentukan dulu siapa yang siap untuk berangkat, lalu ditanyakan apa yang menjadi beban atau kendalanya. Kalau memang ada yang ekonominya masih kurang disiasati dengan sumbangan untuk diberikan kepada keluarga anggota yang akan pergi. Semuanya dipersiapkan, kalau sudah tidak ada kendala baru berangkat." 24

Penuturan yang sama juga disampaikan oleh anggota yang bernama Hama dan Suniyah, seperti dalam petikan wawancara berikut ini :

"Masalah pemenuhan mafkah semuanya sudah diatur dulu sebelum berangkat khurûj. Supaya keluarga yang ditinggalkan tidak terlan tar. Tapi Kalau hanya suami yang ikut, pasti akan menjadi masalah. Soalnya akan terjadi ketidaksepahaman antara suami dan isteri. Namanya juga seperti rumah tangga hanya berjalan dengan satu sayap. Jadi tidak maksimal. Itu yang bisa menjadi pemicu." 25

Setiap malam Rabu diadakan perkumpulan antara anggota Jama`ah Tabligh laki-laki yang disebut dengan 'rijâl'. Selain mem bahas tentang nafkah keluarga ada juga semacam sharing yang dike mas seperti pengajian untuk memberikan tambahan pengetahuan agama kepada semua anggota Jama`ah Tabligh. Perempuan tidak diperkenankan untuk mengikuti musyawarah tersebut karena hanya dikhususkan kepada para anggota laki-laki. Akan tetapi proses musyawarah tersebut bisa didengar melalui pengeras suara masjid.

Apa yang terjadi dengan Jama'ah Tabligh di daerah Paddhek, sama dengan Jama 'ah Tabligh dari Bandung yang tengah melakukan khurûj dan sempat singgah di masjid Baitul Ghufron Paddhek. Beberapa anggota Jama`ah Tabligh Bandung memberikan keterangan dalam petikan wawancara sebagai berikut:

"Kita ada musyawarah lalu pertemuan seperti pengajian bagi yang masih baru bergabung, nanti di masjid di tunjuk siapa yang akan

24 Wawancara dengan Nyai Nikmah, anggota Jamaah Tabligh, pada hari Selasa 20 Januari 2015

25 Wawancara dengan Hama, anggota Jamaah Tabligh, pada hari Selasa 20 Januari 2015. 
berangkat. Kalau sudah dapat nama-nama yang akan berangkat nanti ditanyakan lagi bagimana keluarganya, keuangannya, hutang piutangnya, seperti kredit motor misalnya jadi hal-hal seperti itu jangan sampai dibawa berdakwah. Baru kalau sudah selesai semua permasalahan kita berangkat." 26

Anggota Jama`ah Tabligh mengadakan musyawarah terlebih dahulu untuk menentukan siapa yang siap untuk berangkat khurûj. Setelah ditentukan, kemudian ditanyakan kondisi keuangan keluarga anggota Jama'ah selama ditinggal khurûj. Jika ada kendala pada keuangan, maka diadakan pemberian nafkah silang, yakni saling membantu keluarga yang ditinggalkan dan menjadikannya tanggung jawab bersama.

\section{Kendala Pemenuhan Hak dan Kewajiban Keluarga}

Cara pemenuhan nafkah keluarga anggota Jama`ah Tabligh yang telah dipaparkan merupakan bentuk antisipasi yang telah diatur dan seharusnya dapat terlaksana dengan baik. Dengan demikian agar keharmonisan masing-masing keluarga dapat terjaga, walaupun harus membagi waktu dengan kegiatan berdakwah. Namun, tidak semua anggota Jama`ah dapat menjalankan proses dan konsep ter sebut dengan baik, sehingga mengakibatkan dampak buruk terhadap keluarga.

Salah satu kendala yang terjadi di antara keluarga anggota Jama`ah Tabligh adalah tidak ada kesepahaman antara suami dan isteri. Nyai Nikmah, tokoh perempuan Jama'ah Tabligh menyatakan:

"Masalah itu pasti ada. Ya itu tadi, diakibatkan tidak ada kerelaan dari isteri. Isteri masih belum rela untuk hidup sederhana, dan tidak rela suaminya lebih sering pergi untuk berdakwah dari pada memenuhi kebutuhan keluarga. Akhirnya dari ketidakrelaan tersebut timbullah masalah, sampai mengakibatkan perceraian" 27

Menurut keterangan Nyai Nikmah, anggota Jama'ah Tabligh tidak diperkenankan hidup secara mewah. Setiap anggota yang

\footnotetext{
26 Wawancara dengan Mohammad Harisuddin, anggota Jamaah Tabligh asal Bandung, pada hari Senin 19 Januari 2015

27 Wawancara dengan Ny. Nikmah, anggota Jamaah Tabligh, pada hari Selasa 20 Januari 2015
} 
berkeinginan untuk bergabung dan berkomitmen untuk berdakwah harus bisa hidup sederhana dengan cara yang telah dicontohkan Rasulullah. Saat berdakwah Jama`ah Tabligh selalu diarahkan pada tempat-tempat yang berada di dalam lingkungan sederhana agar tidak mengganggu kekhusukan dakwah.

Hal serupa juga dikemukakan oleh Luthfiyah saat mengikuti acara pengajian Masturah di salah satu musholla dekat masjid Baitul Ghufron. Ibu Luthfiyah menuturkan:

"Karena penghasilan keluarga adalah dari toko. Saya menggantikan suami menjaga toko kalau suami saya sedang khurûj. Kalau saya ya rela saja suami pergi khurûj soalnya alhamdulillah keuangan keluarga sudah stabil. Tapi ada juga isteri anggota Jama`ah Tabligh lainnya yang masih sering mengeluh karena keuangan keluarga yang masih kekurangan, tetapi suaminya memaksa untuk khurûj." 28

Ibu rumah tangga anggota Jama'ah yang dimaksud oleh Luthfiyah tersebut adalah Syarifah. Ia mengaku bahwa memang merasakan kekurangan dalam hal nafkah. Suaminya berangkat $k h u r \hat{u} j$ dengan meninggalkan uang nafkah yang tidak cukup untuk meme nuhi kebutuhan sehari-hari sehingga terpaksa berhutang dan bekerja serabutan demi anak-anaknya. ${ }^{29}$

Kendala lain dialami oleh adik kandung Ayyub, yaitu Zahroh isteri salah satu anggota Jama'ah Tabligh yang sekarang berada di Malaysia. Setelah bercerai dari suaminya dia memutuskan pergi ke Malaysia untuk melunasi hutang keluarga selama ditinggalkan khurûj tanpa nafkah oleh suaminya. Ayyub mengakui bahwa rumah tangga adiknya tersebut mengalami keretakan setelah satu tahun suaminya selalu pergi khurûj. Ayyub mengisahkan :

"Adik ipar saya selalu pergi khurûj, sampai menyebabkan nafkah sama perhatiannya untuk keluarga tidak ada. Sudah tidak kerja, tidak memberikan nafkah sama keluarga. Kerjanya pergi terus. Kata nya untuk berdakwah. Padahal tanpa harus pergi, berdakwah yang saya tahu itu di mana saja. Awalnya isterinya disuruh jual harta benda yang bisa dijual kalau memang sudah tidak ada uang.

${ }^{28}$ Wawancara dengan Luthfiyah, anggota Jamaah Tabligh, pada hari Rabu 21 Januari 2015

29 Wawancara dengan Syarifah isteri anggota Jamaah Tabligh, pada hari Rabu 21 Januari 2015 
Faiqoh Bahjah Lailatus Siyami

Akhirnya perhiasan, hewan peliharaan, sampai tanah dan rumah warisan juga harus ikut dijual untuk menutupi kebutuhan keluarga." 30

Kejadian serupa juga dialami oleh Hajah Halilah orang tua dari Hajah Imamatus Shalihah salah satu anggota Jama `ah Tabligh yang mengalami keretakan dalam rumah tangga. Namun bukan dise babkan oleh kurangnya nafkah materi melainkan kekurangan nafkah secara batin (nafkah biologis), karena menantunya yang bernama Haji Imam Luthfi menikah lagi sewaktu pergi khurûj. Hal tersebut yang awalnya dirahasiakan hingga akhirnya terbongkar sampai meng akibatkan isteri pertamanya, Hajah Imamatus Shalihah mengalami depresi. Hajah Halilah menuturkan :

"Benar menantu saya itu poligami dengan seorang janda yang bertemu di tempat khurûj. Katanya ada yang menjodohkan di sana. Saya kira benar-benar pergi khurûj ternyata kalau khurûj bawa isteri yang kedua. Tapi saya tidak mau memperpanjang urusan itu saya cuma minta itu dicerai isteri mudanya." 31

Menurut keterangan Hajah Halilah, bahkan cucunya juga tidak mau bergaul dengan teman sebaya ataupun dengan ibunya yang masih mengalami depresi, sehingga walaupun secara materi sudah terpenuhi namun secara psikis, isteri dan anak-anaknya kekurangan nafkah kasih-sayang. Hajah Halilah melanjutkan penuturannya:

"Sejak ketahuan menikah lagi di tempat khurûj, isterinya seperti punya penyakit, sering nangis sendiri, kalau suaminya pergi lama jadi curiga dan ngamuk-ngamuk seperti kesetanan. Sampai sempat harus di rawat di rumah sakit Saiful Anwar Malang. Sampai sekarang harus terus check up tiap bulan ke Malang. Mungkin sudah takdir. Anaknya sekarang juga tidak mau lagi sama ibunya karena sering ngamuk. Anak yang laki-laki sekarang yang tidak mau, tidak mau sekolah, ngaji, atau main sama teman-temannya.

\footnotetext{
30 Wawancara dengan Ayyub, keluarga dari anggota Jamaah Tabligh, pada hari Senin 22 Desember 2015

31 Wawancara dengan $\mathrm{Hj}$. Halilah, keluarga dari anggota Jamaah Tabligh, pada hari Minggu 11 Januari 2015
} 
Menyendiri di dalam kamar. Kalau mau makan juga harus di anterin." 32

Setelah mengkonfirmasi kepada Haji Muhammad Saleh selaku kordinator Jama`ah Tabligh daerah pantai utara Madura, tentang berbagai macam kendala pemenuhan hak dan kewajiban suami-isteri anggota Jama`ah Tabligh yang mengakibatkan masalah dalam keluar ga. Meskipun awalnya keberatan untuk menceritakan lebih mendalam mengenai konflik yang banyak terjadi pada keluarga ang gota Jama`ah Tabligh, akhirnya ia bersedia memberikan ketera ngan bahwa ada beberapa anggota yang gemar khurîj tanpa meme dulikan keluarganya. 33

Hal tersebut terjadi karena tidak ada koordinasi program yang diberlakukan secara sistematis dalam Jama'ah Tabligh. Sebagaimana memang tidak pernah ada pengurus, kordinator, bahkan tidak ada pembekalan yang diberikan kepada setiap anggota baru yang berga bung dan akan melaksanakan khurûj. Achmad Syarqawi menuturkan bagaimana persiapan untuk pemahaman tentang dakwah tidak dilakukan karena asumsi menjalankan program khurûj sekaligus belajar langsung di dalamnya. ${ }^{34}$

Menurut Haji Muhammad Saleh bahwa anggota baru yang mempunyai keinginan untuk khurûj maka akan tetap diberangkatkan untuk berdakwah sekalipun ilmu agamanya terbatas. Karena ketika berangkat khurûj secara tidak langsung belajar, sesuai dengan petikan wawancara berikut :

"Walaupun anggota baru kalau punya keinginan untuk khurûj ya diajak. Karena saat perjalanan khurûj dia akan sambil belajar dengan sendirinya. Sebenarnya ini juga menjadi kendala bagi Jama'ah Tabligh untuk mendapatkan respon baik dari masyarakat. Karena kadang ada yang mengetahui bahwa anggota yang pergi untuk khurûj tersebut masih minim dalam masalah agama jadi

32 Wawancara dengan $\mathrm{Hj}$. Halilah, keluarga dari anggota Jamaah Tabligh, pada hari Minggu 11 Januari 2015

33 Wawancara dengan Haji Muhammad Saleh anggota Jamaah Tabligh, pada hari Sabtu 17 Januari 2015

34 Wawancara dengan Ach. Syarqawi anggota Jamaah Tabligh, pada hari Kamis 08 Januari 2015 
masyarakat merasa tidak seharusnya mengaji dari orang yang ilmu agamanya masih belum menguasai." 35

Ditambahkan oleh Achmad Syarqawi bahwa pendidikan juga sangat memengaruhi kualitas para anggota. Menurut pengalamannya di Jama`ah Tabligh, kebanyakan anggota Jama`ah Tabligh di daerah Madura termasuk kampong Paddhek ini hanya ikut-ikutan saja. Achmad Syarqawi menjelaskan :

"Pendidikan dasar dari para anggota itu juga memengaruhi. Jadi saat saya melihat anggota yang bergabung karena ikut-ikutan dengan yang bergabung karena mendalami tentang Jama`ah Tabligh terlebih dahulu itu sangat berbeda. Nah, yang saya temui Jama ah Tabligh di Madura ini seperti itu, hanya ikut-ikutan jadi tidak mantep. Padahal Jama'ah Tabligh itu tidak seperti itu. Awalnya semangat menggebu-gebu setelah beberapa tahun lepas lagi jilbab, lepas lagi ibadahnya." 36

Ayyub menyampaikan pendapatnya mengenai permasalahan yang kerap terjadi pada keluarga anggota Jama`ah Tabligh. Menu rutnya harus ada tahapan bagi anggota yang baru bergabung sehing ga mampu menyesuaikan dengan kondisi ekonominya. Berikut petikan wawancaranya :

"Kalau saya tidak menyalahkan Jama`ah Tabligh, karena apa yang mereka usung adalah sunnah Rasul. Pasti baik. Tapi yang saya sayangkan, harusnya anggota baru seperti adik ipar saya itu harus dicegah dulu untuk sering pergi. Harusnya bertahap sampai benar-benar menyesuaikan dengan kemampuan ekonomi keluarga. Tapi sekarang sudah terlanjur berpisah saya tidak bisa berbuat apa-apa. Adik saya itu pergi ke Malaisya untuk membayar hutang keluarganya yang masih ada."37

Pendapat lain juga disampaikan oleh salah satu tokoh masya rakat Kiai Hayatullah. Ia menuturkan bahwa khurûj seharus nya

35 Wawancara dengan H. Muhammad Saleh anggota Jamaah Tabligh, pada hari Sabtu 17 Januari 2015

36 Wawancara dengan Ach. Syarqawi anggota Jamaah Tabligh, pada hari Kamis 08 Januari 2015

37 Wawancara dengan Ayyub, keluarga dari anggota Jamaah Tabligh, pada hari Senin 22 Desember 2015 
dikhususkan kepada keluarga yang memang sudah mapan secara ekonomi sehingga tidak mengalami masalah materi.

Selain itu suami juga harus memperhatikan penjagaan isteri ataupun keluarga selama ditinggalkan, sehingga isteri tidak akan melakukan hal yang dilarang oleh agama. Berikut pandangan Kiai Hayatullah:

"Saya pribadi adalah orang yang tidak setuju sebenarnya. Jika dihubungkan dengan rumah tangga, saya tidak setuju karena saya punya amanah lain. Saya punya murid yang harus saya perhatikan pendidikannya, kalau saya tinggalkan untuk khurûj mereka akan terbengkalai. Kalau dalam keluarga, mungkin dilihat keluarganya seperti apa. Jika keluarga itu mapan dalam hal ekonomi, sang isteri ridho untuk ditinggal suaminya, suaminya sendiri yakin isterinya ditinggalkan tidak akan macam-macam dengan tidak melakukan hal yang menyalahi aturan agama. Ada nafkah lahir yang ditinggalkan oleh suaminya cukup. Mungkin itu bisa diterima. Tapi jika keluarga yang belum mapan, yang saat masih hidup bersama isterinya saja tidak bisa mencukupi kok malah ditinggalkan keluar untuk khurûj. Saya lebih setuju tentang konsep sederhana dalam Al-Quran, yaitu suami harus hidup dengan isteri dengan baik, itu mutlak kata Allah. 38

\section{Konsep Khurûj dalam Perspektif Hukum Islam: Problem Nafkah Lahir dan Batin}

Sebelum melakukan khurûj para anggota laki-laki Jama`ah Tabligh atau biasa disebut rijâl mengadakan musyawarah untuk menentukan siapa yang siap untuk berangkat. Ketika sudah mene mukan sepakat tentang anggota yang akan khurûj, kemudian diadakan penyeleksian anggota yang layak berangkat dilihat dari kondisi ekonomi keluarga yang akan ditinggalkan. Terdapat dua pilihan, bagi anggota dengan kondisi keluarga berkecukupan dan tidak mengkhawatirkan akan kekurangan saat harus ditinggalkan dalam jangka waktu lama akan langsung diperkenankan berangkat.

Bagi anggota yang masih kurang terutama secara materi maka akan diadakan nafkah silang. Nafkah silang ini adalah dengan saling

\footnotetext{
38 Wawancara dengan K. Hayatullah, salah satu tokoh masyarakat di Kampung Paddhek hari Jumat 30 Januari 2015
} 
membantu baik saling memberi berupa materi ataupun berupa tenaga. Walaupun dalam nash tidak pernah disebutkan cara peme nuhan hak dan kewajiban seperti yang ditempuh oleh anggota Jama`ah Tabligh, namun hal tersebut merupakan cara yang dianggap baik untuk dapat mempertahankan keutuhan keluarga.

Disebutkan dalam sebuah kaidah ushuliyah bahwa perkara yang pada asal boleh (mubah) hukumnya diperbolehkan, kecuali ada dalil yang melarangnya. ${ }^{39}$

$$
\text { الأصل في الأشيأ الأباحة حتى يدل الدليل على التحريم }
$$

Hukum asal dari sesuatu (muamalah) adalah mubah sampai ada dalil yang melarangnya (memakruhkan atau mengharamkannya).

Mengacu pada kaidah ushûliyah di atas pada dasarnya tidak ada yang salah dengan cara yang telah diterapkan oleh Jama'ah Tabligh. Kompilasi Hukum Islam (KHI) dalam Pasal 77 ayat (1) me nyatakan bahwa suami isteri memikul kewajiban yang luhur untuk menegakkan rumah tangga yang sakinah, mawaddah, dan rohmah yang menjadi sendi dasar dan susunan masyarakat. ${ }^{40}$

Ketentuan tersebut berlandaskan pada QS. An-Nisa' [4]: 34. Secara serempak para ulama fiqh mewajibkan nafkah pada isteri atas dasar perintah Al-Quran, sabda Nabi, dan ijma'. Para ulama madzhab sepakat tentang kewajiban pemberian nafkah kepada isteri atas dasar pernikahan yang sah. Pernikahan menjadi salah satu sebab yang mewajibkan pemberian nafkah. Ketetapan tersebut merujuk pada Q.S Al-Baqarah [2]: 233.41 Dengan adanya ikatan perkawinan yang sah, seorang isteri menjadi terikat hanya kepada suaminya. ${ }^{42}$

Disebutkan juga dalam Kompilasi Hukum Islam (KHI) Pasal 80 ayat (5) bahwa isteri dapat membebaskan suaminya dari kewajiban terhadap dirinya sebagaimana disebutkan pada Pasal sebelumnya. Hal ini menunjukkan bahwa meninggalkan isteri untuk khurûj diperbolehkan ketika isteri mengikhlaskan maka kewajiban nafkah bagi suami gugur selama pergi khurûj. Kenyataannya tidak sedikit

\footnotetext{
${ }^{39}$ Amir Syarifuddin, Garis-Garis Besar Fiqih (Jakarta : Prenada Media, 2003)., hlm. 13

40 Tim Redaksi, Kompilasi Hukum Islam (Bandung : Nuansa Aulia, 2012), hlm. 24

41 Muhammad Jawad Mughniyah, Fiqih Lima Madzhab (Jakarta: Lentera, 2002), hlm. 400

42 Sayyid Sabiq, Fiqih Sunnah (Jakarta: Pena Ilmu dan Amal, 2006), hlm, 56
} 
isteri yang tidak menerima pilihan suami untuk pergi khurûj karena harus ditinggalkan dalam waktu lama. Tidak semua isteri dari anggota Jama'ah Tabligh juga bersedia bergabung dan mentaati aturan Jama`ah. Selain kendala yang timbul oleh pihak isteri terdapat juga pelanggaran atas kesepakatan tentang nafkah silang yang melibatkan keluarga-keluarga lain anggota Jama`ah Tabligh.

Konsep nafkah silang mempunyai latar belakang sikap saling membantu sesama muslim. Allah menganjuran sikap saling mem bantu dengan menyebutnya dalam QS. Al-Maidah [5]: 246. Sesuai dengan ayat Allah ini menganjurkan bahwa manusia terutama se sama muslim seharusnya dapat saling tolong menolong dalam memenuhui kebutuhan hidup bermasyarakat. Kehidupan memang tidak pernah dapat terlepas dari permasalahan, karena itu Allah memerintahkan kita untuk saling membantu, berbagi, dan meleng kapi.

Sebagai manusia yang tidak terlepas dari berbagai keter ba tasan tidak mungkin dapat menyelesaikan setiap permasa lahan sendiri dan pasti membutuhkan bantuan dari orang lain. Tidak hanya berhenti pada persoalan tolong menolong. Allah melanjutkan kriteria tolong menolong yang diperbolehkan oleh agama, yaitu adalah tolong menolong dalam hal kebaikan yang dapat membawa kepada ketakwaan seorang hamba kepada Tuhannya. Anjuran tersebut yang menjadi tolak ukur dari adanya nafkah silang.

Mengenai nafkah, Allah telah berfirman dalam QS. Al-Thalaq [65]: 7. Perintah langsung dalam surat tersebut dengan menyebut kata 'laki-laki (suami)' menjadikan kewajiban tersebut menjadi kewa jiban yang bersifat fardlu 'ayn, yaitu kewajiban yang bersifat individu dan secara otomatis melekat pada diri seorang suami ketika telah melakukan akad nikah. Ayat tersebut juga dijadikan dasar dalam Kompilasi Hukum Islam (KHI) Pasal 80 ayat (2) yang mengatakan bahwa 'suami wajib melindungi isterinya dan membe rikan segala sesuatu keperluan hidup berumah tangga sesuai dengan kemam puannya. ${ }^{43}$

Sejalan dengan nash Al-Quran yang menggunakan kata lakilaki/suami yang bertujuan bahwa aturan tersebut memang ditujukan kepada laki-laki/suami. Dalam sebuah Hadits disebutkan bahwa

${ }^{43}$ Tim, Kompilasi, hlm. 25 
menafkahi keluarga merupakan pekerjaan yang diutamakan dari pada pekerjaan amaliah lainnya. Hal ini dapat dikaitkan dengan semangat dakwah Jama`ah Tabligh dalam penelitian ini lebih memen tingkan perjalanan dakwah yaitu khurûj, daripada memenuhi nafkah keluarga.

$$
\text { ودينف ثوبان رضي الله عنه قال : قال رسول الله صلى الله عليه وسلم : أفضل دينار }
$$

"Dari Tsauban, dia berkata, "Rasulullah SAW bersabda, 'harta yang paling utama untuk dinafkahkan oleh seseorang adalah harta yang dinafkahkan untuk keluarganya dan harta yang dinafkahkan untuk hewan (kendaraan yang dipakai) demi membela agama Allah, serta harta yang dinafkahkan untuk pera sahabatnya demi membela agama Allah" 44

Hadits lainnya menyebutkan bahwa keutamaan menafkahi keluarga adalah serupa dengan pahala sedekah. Hal ter sebut sesuai dengan Hadits yang diriwayatkan oleh Abu Mas'ud Al-Badri :

$$
\begin{aligned}
& \text { عن أبي مسعود البدري رضي الله عنه : عن النبي صلى الله عليه وسلم قال : أن } \\
& \text { المسلم أذا أنفق على أهله نفقة وهو يحتسبها. كانت له صدقة }
\end{aligned}
$$

"Dari Abu Mas'ud Al-Badri r.a, dari Nabi SAW, beliau bersabda, 'sesungguhnya jika seseorang muslim memberi nafkah untuk keluarganya karena Allah, maka nafkah tersebut bernilai sedekah baginya" 45

Kewajiban tersebut dapat tetap berlaku selama isteri tidak

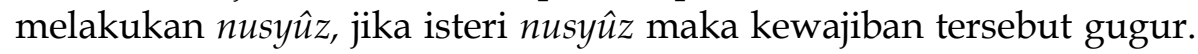
Isteri dianggap nusyûz apabila ia tidak mau melaksanakan kewaji ban-kewajibannya, kecuali dengan alasan yang dibenarkan oleh agama. Ketentuan tersebut disebutkan dalam Kompilasi Hukum Islam (KHI) Pasal 84 ayat (1).

Salah satu yang menjadi kendala dalam pembahasan ini adalah ada ketidakkesepahaman isteri dengan pilihan suami untuk

44 Muhammad Nashiruddin Al-Albani, Mukhtashar Shahih Muslim (Jakarta : Pustaka Azzam)., hlm, 629

45 Ibid., hlm, 630 
bergabung dengan Jama`ah Tabligh. Jika isteri nusyûz karena minus nafkah saat ditinggalkan khurûj, maka alasan tersebut adalah alasan yang dibenarkan oleh agama. Selanjutnya yang menjadi kendala adalah adanya pelanggaran terhadap kesepakatan yang telah dibuat, yaitu penerapan nafkah silang. Kesepakatan dapat disamakan dengan sebuah janji, karena saat musyawarah menemukan kata sepakat untuk mengadakan nafkah silang, hal tersebut menjadi tanggung jawab kepada anggota yang hadir dan menyetujui hasil musyawarah. Memenuhi janji merupakan sebuah kewajiban bagi setiap muslim. Banyak sekali ayat yang menjelaskan kewajiban memenuhi janji. Seperti disebutkan dalam QS. Al-Isra' [17]:3446 QS. Al-An'am [6]: 152, QS. Ar-Ra'du [13]: 20.

Dua kewajiban antara pemenuhan kewajiban suami-isteri dengan kewajiban dakwah mempunyai kekuatan yang sama dengan berlandaskan kepada ayat Al-Quran bahkan dalam kondisi normal kedudukan dalam pemenuhan kewa jiban suami-isteri dalam sebuah keluarga mempunyai kedudukan yang lebih utama dibandingkan dengan kewajiban berdakwah. Kenyataan yang terjadi di masyarakat kampung Paddhek kecamatan Pasean kabupaten Pamekasan pengikut kegiatan Jama ah Tabligh adalah tidak semua isteri dapat mengikuti pilihan dakwah suaminya bersama Jama`ah Tabligh. Tidak semua isteri dengan suka rela menerima kondisi di mana dirinya harus berpisah dengan imam keluarganya dan ditinggalkan dalam waktu lama.

Untuk kondisi tersebut Kompilasi Hukum Islam (KHI) mengatur dua hal. Pertama jika isteri tidak rela dengan keputusan suami yang bergabung dengan Jama'ah Tabligh, maka isteri boleh mengajukan gugatan kepada Pengadilan Agama sebagaimana disebutkan dalam KHI Pasal 77 ayat (5) bahwa 'jika suami atau isteri melalaikan kewajibannya masing-masing dapat mengajukan gugatan kepada Pengadilan Agama'. Kedua, jika ternyata isteri dengan suka rela menerima keputusan suami untuk pergi jauh berdakwah, KHI Pasal 80 ayat (6) mengatakan bahwa 'isteri dapat membebaskan suaminya dari kewajiban terhadap dirinya sebagaimana tersebut pada ayat (4) huruf a dan b. Kewajiban tersebut berupa nafkah kiswah

46 Departemen Agama, mushaf, hlm, 285 
dan tempat kediaman bagi isteri, biaya rumah tangga, biaya perawa tan dan biaya pengobatan bagi isteri dan anak.

\section{Penutup}

Kenyataan yang ditemui di lapangan menunjukkan bahwa tidak semua anggota Jama'ah Tabligh dapat menyelaraskan tanggung jawabnya sebagai kepala keluarga dengan kegiatan dakwah. Konsekuensinya banyak menyebabkan problem bahtera rumah tangga para anggota, seperti perceraian dan kegaduhan rumah tangga. Perceraian harus diambil sebagai jalan keluar dari pertengkaran yang terjadi dalam keluarga. Awal mula timbulnya pertengkaran tersebut adalah faktor kebutuhan ekonomi dalam kehidupan rumah tangga. Nafkah yang diberikan kepada istri sebelum melakukan khurûj, jauh dari mencukupi.

Karena merasa terbebani secara ekonomi, para isteri berupaya mengatasinya dengan meminjam kepada tetangga dan sanak saudara-kerabat. Akhirnya setelah hal tersebut terjadi berulang-ulang sehingga kewajiban menyelesaikan hutang keluarga menjadi menumpuk. Hal demikian tak pelak mengakibatkan perselisihan domestik dan akhirnya perceraian menjadi solusi yang tidak dapat dihindari akibat persoalan yang mengkusut.

Selain faktor ekonomi, perceraian juga menjadi langkah yang diambil oleh keluarga lainnya karena hadirnya pihak ketiga. Hal ini lumrah berawal dari suami yang melakukan khurûj dan bertemu dengan perempuan lain. Dalam pertemuan itulah timbul keinginan untuk menikah lagi. Namun, karena isteri pertama keberatan untuk dipoligami maka terjadi pertengkaran. Bukan mencari penyelesaian untuk rukun, suami memilih menjatuhkan talak tiga kepada isteri pertama. Hal serupa juga terjadi namun tidak sampai menimbulkan perceraian, karena suami lebih memilih untuk menyelamatkan pernikahan yang pertama dan mengikhlaskan isteri kedua dengan menceraikannya. Dampak nyata dari kasus-kasus yang muncul akibat khurûj yang dilaksanakan tanpa perencanaan yang matang adalah ibu-ibu rumah tangga yang tertekan.

Dapat diambil kesimpulan bahwa Jama`ah Tabligh pada dasarnya telah menempuh cara agar agenda kegiatan dakwah Jama`ah Tabligh berupa khurûj tidak banyak mengganggu kehidupan rumah tangga anggotanya. Tradisi khurûj di kalangan Jama`ah 
Tabligh merupakan langkah nyata penyebaran syiar Islam yang tidak semua organisasi Islam mampu melaksanakannya. Namun di balik kegiatan positif tersebut, ditemukan banyak persoalan yang dapat meruntuhkan kesan dan nilai positif khurûj. Persoalan tersebut adalah minus kordinasi dan evaluasi kongkrit dari penyelenggara (pengurus Jama`ah Tabligh), komitmen internal keluarga anggota Jama`ah, konsistensi kepedulian antar keluarga Jama`ah, dan semangat dakwah yang lurus dan tulus.

\section{Daftar Pustaka}

Albani, Muhammad Nashiruddin Al-. Mukhtashar Shahih Muslim (Jakarta: Pustaka Azzam)

Mughniyah, Muhammad Jawad. Fiqih Lima Madzhab, Jakarta: Lentera, 2002

Sabiq, Sayyid. Fiqih Sunnah, Jakarta: Pena Ilmu dan Amal, 2006

Departemen Agama RI, Mushaf Aisyah Al-Qur'an dan Terjemah Untuk Wanita, Jakarta: Hilal, 2010

Hamka. Tafsir Al-Azhar, Jakarta: PT Pustaka Panjimas, 2005

Saebani, Beni Ahmad. Fiqih Munakahat 2, Bandung: CV Pustaka Setia, 2010

Muhyiddin, Asep. Kajian Dakwah Multiperspektif, Bandung: Rosda, 2014

Shihab, M. Quraish. Tafsir Al-Mishbah, Jakarta: Lentera Hati, 2005

Syarifuddin, Amir. Garis-Garis Besar Fiqih, Jakarta: Prenada Media, 2003

Tim Redaksi, Kompilasi Hukum Islam, Bandung: Nuansa Aulia, 2012

Yusuf, Muhammad As-Sayyid et. al, Ensiklopedi Metodologi Al-Quran 1, Mesir: Dar As-Salam Maktabah Al-Usrah, tth

Bungin, Burhan, Analisis Data Penelitian Kualitatif, Rajawali Press : Jakarta, 2010

Moleong, Lexy J., Metodologi Penelitian Kualitatif, (Bandung: PT Remaja Rosdakarya, 2005)

Suharsimi Arikunto. Prosedur Penelitian (Jakarta: PT Rineka Cipta, 2010)

Sugiono. Metode Penelitian Kuantitatif Kualitatif dan RED, (Bandung: Alfabeta, 2011) 


\section{Internet}

http:/ / m.nu.or.id/a,public-m,dinamic-s,detail-ids,4-id,32537-lang,idc,kolomt,Jama ah+Tabligh-.phpx (diakses pada hari Jum'at tanggal 21 Maret 2014. 20.52 WIB)

http://m.nu.or.id/a,public-m,dinamic-s,detail-ids,4-id,32537-lang,idc,kolomt,Jama`ah+Tabligh-.phpx (diakses pada hari Jum'at tanggal 21 Maret 2014. 20.52 WIB)

http:/ / abusalma.wordpress.com/2007/01/03/studi-kritispemahaman-Jama`ahTabligh/(diakses pada hari Kamis tanggal 27 Maret 2014. 17.47 WIB) 